Kalem Eğitim ve İnsan Bilimleri Dergisi 2019, 9(1), 155-175, doi: 10.23863/kalem.2019.123

Makale Gönderim Tarihi:13.04.2018 Makale Kabul Tarihi: 26.06.2018

\title{
An Intercultural Study on Flute Instruction in Music Teacher Training Programs (The German and Turkish Examples)
}

\author{
Asst. Prof. Raziye Nil AKSOY* \\ Aksaray Üniversitesi, Eğitim Fakültesi, Güzel Sanatlar Eğitimi Bölümü, Aksaray / Türkiye, \\ nilaksoy.20@gmail.com, ORCID: 0000-0001-9191-0381

\section{Prof. Salih AKKAŞ} \\ Gazi Üniversitesi, Eğitim Fakültesi, Güzel Sanatlar Eğitimi Bölümü, Ankara / Türkiye, \\ sakkas@gazi.edu.tr, ORCID: 0000-0002-9753-5364
}

\begin{abstract}
The main objective of the present study was to determine the similarities and differences between flute instruction in music teacher training programs in Turkish and German universities, which possess significant qualities in flute instruction, and thus, to provide different perspectives for flute instructors and contribute to flute instruction in Turkey. Relational screening method, which is a general screening model based on the determination of correlations by comparison, was used in the present descriptive study. The study group included 26 flute instructors employed in music teacher training institutions in Turkey and Germany. Analysis of the quantitative data collected with the survey method was conducted with IBM SPSS 20.0 software and frequency and percentage tables were generated, Mann-Whitney U-Test was used to compare the two groups and analysis results were interpreted at
\end{abstract}


0.05 significance level. In conclusion, both similarities and differences were identified between the flute instruction structures of the countries.

Keywords: Flute teaching; Instrumental teaching; Music teacher training; Music education; Comperative education; Turkey; Germany.

\title{
Müzik Öğretmeni Yetiştiren Programlardaki Flüt Öğretimi Üzerine Kültürlerarası bir Çalışma (Türkiye ve Almanya Örneği)
}

\begin{abstract}
$\ddot{\mathbf{O z}}$
$\mathrm{Bu}$ araştırmanın temel amac1, Türkiye'deki üniversitelerin müzik öğretmeni yetiştiren programlarındaki flüt öğretimi ile flüt öğretimi alanında önemli özellikleri olan Almanya'daki üniversitelerin müzik öğretmeni yetiştiren programlarındaki flüt öğretimi arasındaki benzerlik ve farklılıkların ortaya konması ve bu yolla flüt eğitimcilerine farklı bakış açıları sunularak Türkiye'deki flüt öğretimine katkılar sağlanmasıdır. Bu betimsel araştırmanın yürütülmesinde; karşılaştırma yoluyla ilişki saptamaya dayalı genel tarama özelliği taşıyan ilişkisel tarama modeli kullanılmıştır. Çalışma grubunu Türkiye ve Almanya'da müzik öğretmeni yetiştiren kurumlarda çalışan 26 flüte eğitimcisi oluşturmuştur. Anket tekniğiyle toplanan nicel verilerinin analizi için IBM SPSS 20.0 paket programları kullanılarak frekans, yüzde tablolarına yer verilmiş, iki grubun karşılaştırılmasında Mann-Whitney U-Testi kullanılmış, analizler için elde edilen sonuçlar 0.05 anlamlılık düzeyinde yorumlanmıştır. Sonuç olarak her iki ülkenin flüt öğretim yapıları arasında hem benzerlik hem de farklılıklar belirlenmiştir.
\end{abstract}

Anahtar Kelimeler: Flüt öğretimi; Çalgı öğretimi; Müzik öğretmenliği eğitimi; Müzik eğitimi; Karşılaştırmalı eğitim; Türkiye; Almanya.

\section{Introduction}

Flute instruction is conducted in professional music training institutions, music education departments in fine arts education colleges in faculties of education, in state conservatories, faculties of fine arts at undergraduate, graduate and doctorate levels in Turkey. Flute instruction is included in music teaching undergraduate problem in Individual Instrument (Flute) course, which is instructed for 8 semesters and 1 hour per week. It is observed that there is no common curriculum for flute instruction except a short goals and descriptions about the "flute course" in the curriculum draft 
developed by Council of Higher Education (CHE) for flute instruction at especially the undergraduate level in teacher training institutions in Turkey (YÖK). It is possible to argue that flute instruction differs in every institution. This prevents an effective flute instruction, which requires certain goals and regularly and planned progress to achieve these goals.

Germany is one of the countries in Europe with the oldest universities dating back to 1948 (Hainmüller, 2003), art education in Germany has a long tradition. As an instructional topic, the roots of music have been firmly established in the curriculum since the 1880 s, although they date back to the reformation era when the arts education was structured. The first public music school was established in 1923. At the present, the state supports 9093 music schools (Keucheland Larue, 2014). In Germany, vocational education in music is provided in music academies, scientific, pedagogic and vocational schools of higher education, church music schools of higher education, vocational academies, public and private education centers for popular music or performance arts, and special education institutions for the production of musical instruments (MIZ, 2011; Nimczik, Bassler and Altenburg, 2011). Fine arts and music colleges offer education programs in music disciplines and related academic disciplines (arts, art history, musicology, musical history, music education) and also provide training for arts and music teachers (Erginer, 2012) In the main departments of the Fine Arts and Music schools of higher education, Bachelor's and Master's degree courses can be instructed for up to six years (EURYDICE, 2013a). The State Education Ministers Conference has determined four years for the undergraduate degree, and further two yearsfor the master's degree. Otherwise, at least three years are required for higher education and, if necessary, one or two additional years were anticipated (Nimczik, Bassler and Altenburg, 2011).

In flute education, due to the facts that the flute was introduced to Europe via Eastern Rome from Asia and initially emerged in Germany (Tatu, 2008), the flute obtained its current structure and technical properties about 170 years ago as a result of the work by German flutist Teobalt Böhm (Meylan, 1988; Solum, 1992; Toff, 1996), the contributions of German flute virtuoso Quantz to flute mechanics (Toff, 1996) and the fact that his flute method is one of the oldest and most important flute methods written (Tatu, 2008), Germany could be considered as a well-established and central country in flute education. 
Based on the above mentioned issues, the present study aimed to determine the similarities and differences between the flute instruction in music teacher training programs in Turkish universities and the flute instruction in music teacher training programs in German universities to contribute the flute instruction in music teacher training programs in Turkish universities. Thus, the research problem of the present study was determined as follows; "What are the similarities and differences between the flute instruction in music teacher training programs in Turkish universities and the flute instruction in music teacher training programs in German universities?" The sub-problems that will be solved based on the main research problem are:

1. According to the participants in Turkey and in Germany, is there a difference in the inclusion of flute instruction topics based on school years in flute instruction between Turkey and Germany?

2. According to the participants in Turkey and in Germany, what are the instruction methods used in flute instruction based on the instruction topics?

3. According to the participants in Turkey and in Germany, what are the recommended resources in tone development and sonority, gammes, arpeggios, and etude studies?

4. According to the participants in Turkey and in Germany, how the measurement and evaluation is conducted in flute instruction?

It is considered that the determination of the current situation of the field of flute education in Turkey and its comparison with flute instruction in Germany would contribute to flute education in Turkey. Literature review demonstrated that studies on flute instruction in music teacher training institutions covered only particular topics and there are only limited number of studies conducted on the current status of flute instruction in Turkey and its situation among the international practices. Literature review demonstrated that only Kara (2010) investigated overall flute instruction in Turkey in a study that also compared the findings internationally Literature review also demonstrated certain papers that studied flute education in Turkey. İğdeli (1994) studied the flute instruction in music education departments and presented recommendations. In a study by Gedik (1999), the topics included in flute instruction were determined and a draft curriculum was developed. In a study by Yayla (2000), the fundamental behavior in flute education were determined and the level of students' acquisition of these behavior was in- 
vestigated. Cüceoğlu (2002) developed a flute instruction program for music teacher training programs in a study. Uyan (2005) determined the topics in flute instruction and examined the utilized etudes and works based on goals and target behaviour. In another study, Cüceoğlu (2006) conducted a comparison to demonstrate the status of flute education based on the views of flute instructors in 2001 and 2006. Ekebalkan (2007) mentioned several topics included in flute education in a study. In a study by Ataman (2010), a flute instruction curriculum was designed.

The present study is significant since it aims to fill this gap in the literature. It is very important to follow the international standards in flute education as it is in the instruction of all western music instruments. It is considered that the present study will assist flute instructors to improve their instructional methods and to achieve different instructional perspectives. The study is also significant in illuminating the curricula studies that would be conducted on flute education.

\section{Method}

\section{Research Model}

The present study was conducted with relational screening model, a general screening method, based on determination of the correlation by comparison. In the study, the current status of flute instruction in Turkey is determined by the information provided by flute teachers employed in the mentioned universities and compared to the current situation in Germany. This study is a comparative educational research in music education, in general, and flute education, a dimension of music education, in particular.

\section{Study Group}

Criterion sampling method, a purposive sampling method, was used to determine the study group in the current study. The study criterion was that the participants were flute instructors employed in music teacher training programs. Only volunteering participants were included in the study. The flute instruction survey was sent to 24 flute instructors employed in 19 of the 22 active fine arts education college music education departments, however only 16 flute instructors employed in Ataturk University, Balıkesir University, Cumhuriyet University, Dokuz Eylül University, İnönü University, Karadeniz Technical University, Mehmet Akif Ersoy University, Sitkı Koçman University, Niğde University, On Sekiz Mart University, Pamuk- 
kale University, Selçuk University and Uludağ University accepted to participate in the study.

There are 14 music teacher training institutions in Germany. The flute instruction survey was sent to flute instructors employed in these institutions, however 10 flute instructors from five institutions agreed to participate in the survey. These institutions were: Pädagogische Hochschule Heidelberg, Pädagogische Hochschule Freiburg, Musikhochschule Lübeck, Hochschule für Musik und Theater München, and Musikhochschule Münster. Thus the study group included 16 flute instructors from Turkey and 10 flute instructors from Germany.

\section{Data Collection}

A flute instruction survey was designed to collect the study data. The survey was designed based on the expert opinion of a flute instructor, a flute performer and a measurement and evaluation specialist. The survey included 20 5-point likert type questions out of which 4 were open questions with short answers and 34 were multiple choice questions. The flute instruction survey form was translated to German for distribution in Germany. The flute instruction survey form that was designed to collect the study data was presented to flute instructors in Turkish music teacher training institutions via Google Drive and it was presented to flute instructors in German music teacher training institutions via the Survey Monkey (www.surveymonkey.com) and the responses were collected online. Literature review was the other data collection method used in the present study.

\section{Data Analyses}

For the analysis of quantitative study data, initially the Kolmogorov-Smirnov test was used to determine whether the data exhibited normal distribution. The Mann-Whitney U-Test was used to compare two groups since the scale dimensions did not exhibit a normal distribution. The analysis results were interpreted based on the 0.05 significance level in the study. Furthermore, frequencies and percentages were calculated for quantitative data analysis in the study. The analyses were conducted with IBM SPSS 20.0 software.

\section{Findings}

\section{Findings on the Inclusion of Flute Instruction Topics}

Findings on the inclusion of the flute instruction topics demonstrate 
that breathing exercises were concentrated in the freshman year in Turkey (41\%) and Germany (45\%). It is observed that the vibrato technique was concentrated in the junior and senior years in both countries (38.7), (38.9). The fluttering technique was instructed mainly in the senior year in both countries (53.3), (41.7). The small intervals (38.1), (55.6), whistling (53.3), (53.8), glisando (50.0), (45.5) techniques were also intensive in the senior year in both countries. Multiphonic techniques were instructed in junior and senior years in Turkey (31.2), in the senior year in Germany (61.5), harmonics were mainly instructed in the senior year in Turkey (38.1) and in the junior and senior years in Germany (41.2). Gammes with six flats were concentrated in the senior year in both Turkey and Germany. It could be stated that the gammes with seven flats and seven sharps and chromatic gammes were mostly instructed during the senior year in both countries.

Sonority exercises are predominantly instructed in the sophomore year in Turkey (36.8\%), while the same studies are conducted during the junior $(40 \%)$ and senior (35\%) years in Germany. The interval exercises are instructed mostly in the sophomore year in Turkey (33.3\%) and in the junior year in Germany (38.9\%). In Turkey, arpeggio exercises are instructed predominantly in the sophomore year (31.1\%) and in the junior year in Germany $(41.2 \%)$. Gammes with three sharps are instructed predominantly in the sophomore year in (30.4\%) and in the junior year in Germany (46.7\%). Gammes with three flats are mostly instructed during the freshman and sophomore years in Turkey, whereas these are instructed in the junior year in Germany mostly. Double tonguing technique is instructed in the junior year in Turkey (36.7\%) and in the senior year in Germany (42.9\%). A similar approach is true for the triple tonguing technique. In gammes with five sharps, five flats and six sharps, the instruction is concentrated in the junior year in Turkey and in the senior year in Germany. Techniques used to obtain color of sound and expression terms in flute are instructed in the senior year in Turkey (34.3) and in the junior year in Germany (35.7). Gammes with a single sharp, single flat, two sharps and two flats are instructed predominantly during the freshmen year in Turkey and during the junior and senior years in Germany. Gammes with four sharps and four flats are mostly instructed in the sophomore year in Turkey (33.3\%) and in the senior year in Germany $(50 \%)$. The gammes without alteration are instructed in the freshmen year in Turkey (44.4) and in junior and senior years in Germany (40.0). 


\section{Findings on the Instructional Methods Used Based on the Flute Instruction Topics}

The least utilized method in the instruction of the history of flute was lettered and numerated music instruction method both in Turkey (75) and Germany (90). The second least used method was field trip-observation-investigation method in Turkey and field trip-observation-investigation, problem solving and collaborative instruction methods in Germany. The most commonly used method was the instruction method in Turkey (50) followed by research-investigation method (56). In Germany, most commonly used method was the instruction method (50) followed by the question-answer method (60). In general, the table demonstrates that the methods included in the table were utilized at a lower degree in Germany.

In the instruction of the materials and mechanism of Böhm flute, several methods are utilized at a lower degree in Germany. For instance, the field trip-observation-investigation method is never used in Germany, while this method is extensively used in Turkey. The most commonly used method in Germany is the instruction (40) and the question-answer methods (50). In Turkey, the demonstration method (62.5) is observed to be prominent. Both in Turkey (81.3) and Germany (90.3), the lettering and numerating method is the least used method.

In the instruction of the maintenance and repair properties of the flute, it was observed that certain methods are never used in Germany. The research/analysis method, the method of music instruction through study/practice, and the lettering and numerating method are not practiced in Germany at all. In Turkey, at least utilized method was again the lettering and numerating method (75). The most frequently used method in Turkey is the demonstration method (75). The most commonly used method in Germany is the question-and-answer method.

The utilization of the methods used in flute playing posture is more frequent in Turkey when compared to Germany. The most frequently used method in Germany is the most question-answer method (40), and demonstration method in Turkey (93.8). Both in Turkey (75) and Germany (100), it was observed that the least used method was the lettering and numerating music instruction method. 
The frequency of the breathing techniques in flute instruction is higher in Turkey when compared to Germany. In Germany, the most common method is the question-answer method (40) and the most common methods are the demonstration (87.5) and instruction of music through study/practice (81.3) methods in Turkey. This is followed by the instruction method. The least common method is lettering and numerating music instruction method in Turkey (81.3). The field trip-observation-investigation method (100,) and the lettering and numerating music instruction method (100,) are never used in Germany.

It was observed that the most commonly used methods in Germany are the question-answer method (60), the instruction method (50) and the demonstration method (50) in the instruction of the flute embouchure and tone blowing technique. In Turkey, the demonstration method (87.5) and the method of music instruction through study/practice (81.3) are the most commonly used methods.

In the instruction of tonguing techniques in flute, it was observed that the most commonly used methods in Germany are the instruction (40) and the question-answer (50) methods. In Turkey, the demonstration method (81.3) and the method of music instruction through study/practice (81.3) are the most commonly used methods.

In the instruction of flute hand positions and fingering, it was observed that the most used method (60) in Germany is the demonstration method. In Turkey, the demonstration method (81.3) and the method of music instruction through study/practice (81.3) are the most commonly used methods.

In the instruction of playing the flute with articulation and legato, the most common method was the demonstration method both in Turkey (81.3) and Germany (40). In addition, the instruction method in Germany (40) and the method of music instruction through study/practicein Turkey (81.3) are also utilized.

In the instruction of staccato technique in flute, the most frequently used method is the demonstration method both in Germany (60) and in Turkey (87.5). Furthermore, the method of music instruction through study/practice is rarely used in Germany (70), while it is among the most common methods in Turkey (81.3). In Turkey, question-answer method is 
rarely used (37.5), however the method is commonly used in Germany (50).

In the instruction of marcato flute technique, it can be stated that the most common method in Germany is the demonstration method (50,). In Turkey (81.3), the demonstration method is similar and the method of music instruction through study/practice is also frequently used in Turkey (75), while it is rarely used in Germany (70).

In the instruction of the vibrato technique in flute, it can be stated that the instruction method is the most common method in Germany (30). Furthermore, the question-answer method is also used extensively in Germany (30). In Turkey, the demonstration method (75) and the method of music instruction through study/practice most frequently (87.5) are the most frequently used methods.

In the instruction of gammes in flute, the demonstration method is frequently used in Germany (60) and Turkey (81.3). In Germany, the instruction method (50) and in Turkey, the method of music instruction through study/practice (81.3) are among the most common methods.

In the instruction of nuans terms in flute, the demonstration method is extensively used in Turkey (75) and Germany (70). It can be stated that the most used method in Germany (30) is the instruction method. In Turkey, the method of music instruction through study/practice is the most frequently used method (81.3).

In the instruction of trill in flute, the demonstration method is used frequently in Turkey (81.3) and Germany (60). It can be stated that the most common methods are the instruction (30) and research/analysis methods in Germany (30). In Turkey, the method of music instruction through study/practice is observed as the most common method (81.3). It was determined that the field trip-observation-investigation method and the lettering and numerating music instruction method are never used in Germany.

In the instruction of the techniques used to obtain colorof sound and expression terms in flute, the demonstration method is extensively used in Turkey (75) and Germany (70). The most commonly used methods in Germany are the instruction method (30) and the method of research/analysis (30). In Turkey, the most frequently used method is the method of music instruction through study/practice (75). It was determined that the field trip-observation-investigation method and the lettering and numerating mu- 
sic instruction method are never used in Germany.

In the instruction of sonority in flute, it was observed that several methods are used very little in Germany. The most commonly used methods in Germany are the instruction (40) and the question and answer methods (40). In Turkey, it was observed that the demonstration method (81.3) and the method of music instruction through study/practice (81.3) are widely used.

In the instruction of modern flute techniques, it can be stated that the most common method is the demonstration method (50) in Germany. In Turkey, the demonstration method (81.3) and the method of music instruction through study/practice (68.8) is observed to be the most commonly used methods. The collaborative instruction method, the field trip-observation-investigation method and the lettering and numerating music instruction method are never used in Germany.

In the instruction of the interpretation of composers in flute music, collaborative instruction method, the field trip- observation- investigation method, and the lettering and numerating music instruction method are never used in Germany. In Germany, the instruction method is the most common method (40). In Turkey, the least used method is the lettering and numerating music instruction method (81.3), while the most frequently used method is the demonstration method (68.8). This is followed by the method of music instruction through study/practice (62.5).

In the instruction of tradition of musicstyles in flute, it was determined that the collaborative teaching method and the lettering and numerating music instruction method are never used in Germany. The most commonly used method in Germany is the instruction method. The least used method is the lettering and numerating music instruction method in Turkey (56.3), while the most common method is the demonstration method (81.3). This is followed by the method of music instruction through study/practice (68.8).

As seen in Table 1, Mann Whitney-U Test conducted to determine whether the methods differed between the two countriesbased on instruction topics demonstrated that the difference between the two countries was statistically significant $(p<0.01)$. 
Table 1. Mann-Whitney Test Findings on the Comparison of Instruction Methods Utilized Based on the Topics in Flute Instruction in Turkey and Germany

\begin{tabular}{|c|c|c|c|c|c|c|c|}
\hline Instructed topic & Country & $\mathbf{N}$ & Average & $\begin{array}{l}\text { Average } \\
\text { rank }\end{array}$ & $\begin{array}{c}\text { Rank } \\
\text { total }\end{array}$ & $\mathbf{U}$ & $p$ \\
\hline \multirow[t]{2}{*}{ The history of flute } & Turkey & 16 & 3.10 & 17.59 & 281.50 & $14.5^{* *}$ & 0.00 \\
\hline & Germany & 10 & 1.89 & 6.95 & 69.50 & & \\
\hline \multirow{2}{*}{$\begin{array}{l}\text { Materials and mechanism } \\
\text { of Böhm flute features }\end{array}$} & Turkey & 16 & 3.10 & 18.25 & 292.00 & $4.0^{* *}$ & 0.00 \\
\hline & Germany & 10 & 1.67 & 5.90 & 59.00 & & \\
\hline \multirow{2}{*}{$\begin{array}{l}\text { Maintenance and repair } \\
\text { of the flute }\end{array}$} & Turkey & 16 & 3.18 & 18.44 & 295.00 & $1.0^{* *}$ & 0.00 \\
\hline & Germany & 10 & 1.87 & 5.60 & 56.00 & & \\
\hline \multirow[t]{2}{*}{ Flute posture } & Turkey & 16 & 3.33 & 18.44 & 295.00 & $1.0^{* *}$ & 0.00 \\
\hline & Germany & 10 & 1.84 & 5.60 & 56.00 & & \\
\hline \multirow[t]{2}{*}{ Flute breathing technique } & Turkey & 16 & 3.44 & 18.31 & 293.00 & $3.0^{* *}$ & 0.00 \\
\hline & Germany & 10 & 2.04 & 5.80 & 58.00 & & \\
\hline \multirow{2}{*}{$\begin{array}{l}\text { Embouchure and tone } \\
\text { blowing technique }\end{array}$} & Turkey & 16 & 3.40 & 18.13 & 290.00 & $6.0^{* *}$ & 0.00 \\
\hline & Germany & 10 & 2.21 & 6.10 & 61.00 & & \\
\hline \multirow[t]{2}{*}{ Tonguing techniques } & Turkey & 16 & 3.44 & 18.03 & 288.50 & $7.5^{* *}$ & 0.00 \\
\hline & Germany & 10 & 2.21 & 6.25 & 62.50 & & \\
\hline \multirow{2}{*}{$\begin{array}{l}\text { Flute hand position and } \\
\text { fingering }\end{array}$} & Turkey & 16 & 3.34 & 17.78 & 284.50 & $11.5^{* *}$ & 0.00 \\
\hline & Germany & 10 & 2.09 & 6.65 & 66.50 & & \\
\hline \multirow{2}{*}{$\begin{array}{l}\text { Flute playing with artic- } \\
\text { ulation and legato }\end{array}$} & Turkey & 16 & 3.24 & 18.09 & 289.50 & $6.5^{* *}$ & 0.00 \\
\hline & Germany & 10 & 2.08 & 6.15 & 61.50 & & \\
\hline \multirow[t]{2}{*}{ Staccato technique } & Turkey & 16 & 3.23 & 17.16 & 274.50 & $21.5^{* *}$ & 0.00 \\
\hline & Germany & 10 & 2.33 & 7.65 & 76.50 & & \\
\hline \multirow[t]{2}{*}{ Marcato technique } & Turkey & 16 & 3.22 & 17.78 & 284.50 & $11.5^{* *}$ & 0.00 \\
\hline & Germany & 10 & 2.11 & 6.65 & 66.50 & & \\
\hline \multirow[t]{2}{*}{ Vibrato technique } & Turkey & 16 & 3.40 & 18.13 & 290.00 & $6.0^{* *}$ & 0.00 \\
\hline & Germany & 10 & 1.93 & 6.10 & 61.00 & & \\
\hline \multirow[t]{2}{*}{ Gammes in flute } & Turkey & 16 & 3.26 & 17.94 & 287.00 & $9.0^{* *}$ & 0.00 \\
\hline & Germany & 10 & 1.87 & 6.40 & 64.00 & & \\
\hline \multirow{2}{*}{$\begin{array}{l}\text { Application of nuance } \\
\text { terms in flute }\end{array}$} & Turkey & 16 & 3.30 & 17.59 & 281.50 & $14.5^{* *}$ & 0.00 \\
\hline & Germany & 10 & 2.08 & 6.95 & 69.50 & & \\
\hline \multirow[t]{2}{*}{ Flute trill } & Turkey & 16 & 3.31 & 17.81 & 285.00 & $11.0^{* *}$ & 0.00 \\
\hline & Germany & 10 & 2.11 & 6.60 & 66.00 & & \\
\hline \multirow[t]{2}{*}{ Flute sonority } & Turkey & 16 & 3.34 & 18.00 & 288.00 & $8.0^{* *}$ & 0.00 \\
\hline & Germany & 10 & 2.08 & 6.30 & 63.00 & & \\
\hline \multirow[t]{2}{*}{ Modern flute techniques } & Turkey & 16 & 3.28 & 17.63 & 282.00 & $14.0^{* *}$ & 0.00 \\
\hline & Germany & 10 & 2.02 & 6.90 & 69.00 & & \\
\hline \multirow{2}{*}{$\begin{array}{l}\text { Interpretation of com- } \\
\text { posers in flute music }\end{array}$} & Turkey & 16 & 3.44 & 17.63 & 282.00 & $14.0^{* *}$ & 0.00 \\
\hline & Germany & 10 & 2.07 & 6.90 & 69.00 & & \\
\hline \multirow{2}{*}{$\begin{array}{l}\text { Tradition of music styles } \\
\text { in flute }\end{array}$} & Turkey & 16 & 3.56 & 18.34 & 293.50 & $2.5^{* *}$ & 0.00 \\
\hline & Germany & 10 & 2.04 & 5.75 & 57.50 & & \\
\hline \multirow{2}{*}{$\begin{array}{l}\text { Obtaining color of sound } \\
\text { and expression terms in } \\
\text { flute }\end{array}$} & Turkey & 16 & 3.35 & 17.63 & 282.00 & $14.0^{* *}$ & 0.00 \\
\hline & Germany & 10 & 2.09 & 6.90 & 69.00 & & \\
\hline
\end{tabular}


Analysis of the mean values showed that the instruction methods used in Turkey based on the topics were implemented more when compared to the instruction methods used in Germany based on the topics.

\section{Findings on the Recommended Resources in Flute Instruction}

\section{Distribution of the Resources Recommended for Tone Develop- ment and Sonority Exercises Based on the Countries}

The three most prominent resources recommended in tone development and sonority exercises in Turkey were Marcel Moyse; De La Sonorite (35.6\%), Marcel Moyse; Tone Development Through Interpretation (22.2\%) and Trevor Wye; Practice book for the flute Vol. 1 - Tone (20\%), respectively, while in Germany Marcel Moyse; De La Sonorite (25.7\%), Marcel Moyse; Tone Development Through Interpretation (22.9\%) and Robert Dick; Tone Development Through Extended Techniques (20\%) were recommended in Germany, respectively.

\section{Distribution of the Resources Recommended for Gammes, Ar- peggio and Interval Exercises Based on the Countries}

The three most prominent resources recommended in gammes, arpeggio and interval exercises in Turkey were G. Gariboldi; Etude Complete des Gammes, op. 127 (21.2\%), Marcel Moyse; Gammes et Arpeges (19.7\%) and Th. W. Stepanow; Scales, Chords and Arpeggios (15.2\%), while Marcel Moyse; Gammes et Arpeges (34.8\%), Marcel Moyse; Mecanisme-Chromatisme (26.1\%) and Joachim Andersen; Schule der Virtuositat $(17.4 \%)$ were the three most prominent resources recommended in scale, arpeggio and pitch exercises in Germany

\section{Distribution of the Resources Recommended For Etudes Based on the Countries}

The three most prominent resources recommended in etudes in Turkey were Ernesto Kohler; Op 33/1 Fifteen Etudes (5.5\%), Ernesto Kohler; Op 33/2 Twelve Etudes (5.1\%) and Ernesto Kohler; Op 33/3 Eight Etudes and Ernesto Kohler; Op 66 Romantic Etudes (4.8\%), while SigfridKarg-Elert; Op107 Thirty Caprice (5\%), Andersen; 24 Etudes for Flute Op 15 (4.3\%) and TeobaldBöhm; 24 Caprices- op.26 (4.3 and) were the three most prominent resources recommended in etudes in Germany. 


\section{Findings on the Flute Instruction Measurement and Evaluation}

Table 2. Comparison of Measurement and Evaluation Scoring Based on the Countries

\begin{tabular}{|c|c|c|c|c|c|c|c|}
\hline Dimension & Country & $\mathbf{N}$ & Rank & $\begin{array}{c}\text { Average } \\
\text { Rank }\end{array}$ & $\begin{array}{l}\text { Rank } \\
\text { Total }\end{array}$ & $\mathbf{U}$ & $p$ \\
\hline \multirow{2}{*}{$\begin{array}{l}\text { Correct grip, playing } \\
\text { with posture }\end{array}$} & Turkey & 16 & 7.08 & 11.17 & 134.00 & \multirow[t]{2}{*}{40.0} & \multirow[t]{2}{*}{0.57} \\
\hline & Germany & 10 & 6.25 & 9.50 & 76.00 & & \\
\hline \multirow{2}{*}{$\begin{array}{l}\text { Playing with correct } \\
\text { blowing technique }\end{array}$} & Turkey & 16 & 7.92 & 10.04 & 120.50 & \multirow[t]{2}{*}{42.5} & \multirow[t]{2}{*}{0.42} \\
\hline & Germany & 10 & 11.11 & 12.28 & 110.50 & & \\
\hline \multirow{2}{*}{$\begin{array}{l}\text { Playing with correct } \\
\text { tuning }\end{array}$} & Turkey & 16 & 13.75 & 12.50 & 150.00 & \multirow[t]{2}{*}{48.0} & \multirow[t]{2}{*}{0.46} \\
\hline & Germany & 10 & 12.50 & 10.30 & 103.00 & & \\
\hline \multirow{2}{*}{$\begin{array}{l}\text { Playing the correct } \\
\text { note }\end{array}$} & Turkey & 16 & 13.75 & 13.75 & 165.00 & \multirow[t]{2}{*}{$9.0^{* *}$} & \multirow[t]{2}{*}{0.00} \\
\hline & Germany & 10 & 6.88 & 5.63 & 45.00 & & \\
\hline \multirow[t]{2}{*}{ Correct articulation } & Turkey & 16 & 10.00 & 14.33 & 172.00 & \multirow[t]{2}{*}{$14.0^{* *}$} & \multirow[t]{2}{*}{0.00} \\
\hline & Germany & 10 & 5.56 & 6.56 & 59.00 & & \\
\hline \multirow{2}{*}{$\begin{array}{l}\text { Playing with tone } \\
\text { quality }\end{array}$} & Turkey & 16 & 12.50 & 13.04 & 156.50 & \multirow[t]{2}{*}{41.5} & \multirow[t]{2}{*}{0.23} \\
\hline & Germany & 10 & 10.50 & 9.65 & 96.50 & & \\
\hline \multirow{2}{*}{$\begin{array}{l}\text { Playing with the } \\
\text { right rhythm }\end{array}$} & Turkey & 16 & 10.42 & 12.38 & 148.50 & \multirow[t]{2}{*}{37.5} & \multirow[t]{2}{*}{0.25} \\
\hline & Germany & 10 & 8.89 & 9.17 & 82.50 & & \\
\hline \multirow{2}{*}{$\begin{array}{l}\text { Playing with the style } \\
\text { of tradition features }\end{array}$} & Turkey & 16 & 7.92 & 10.54 & 126.50 & \multirow[t]{2}{*}{48.5} & \multirow[t]{2}{*}{0.46} \\
\hline & Germany & 10 & 11.00 & 12.65 & 126.50 & & \\
\hline \multirow[t]{2}{*}{ Playing with nuance } & Turkey & 16 & 8.92 & 11.50 & 138.00 & \multirow[t]{2}{*}{36.0} & \multirow[t]{2}{*}{0.38} \\
\hline & Germany & 10 & 7.50 & 9.00 & 72.00 & & \\
\hline \multirow{2}{*}{$\begin{array}{l}\text { Interpretation } \\
\text { quality, sonorite }\end{array}$} & Turkey & 16 & 7.75 & 6.79 & 81.50 & \multirow[t]{2}{*}{$3.50^{* *}$} & \multirow[t]{2}{*}{0.00} \\
\hline & Germany & 10 & 28.33 & 16.61 & 149.50 & & \\
\hline
\end{tabular}

Table 2 demonstrates that there was no statistically significant between the countries based on correct grip, playing with correct posture, playing with correct blowing technique, playing with correct tuning, playing with tone quality, and playing with the right rhythm $(p>0.05)$. On the other hand, scores for playing the correct note and correct articulation differed significantly among the countries $(p<0.01)$. Based on mean values, it was observed that the playing the correct notes and correct articulation scores were higher in Turkey. While mean playing the correct notes score in Turkey was 13.75 over 100, the same was 6.88 in Germany. While mean correct articulation score was 10.00 out of 100 in Turkey, the same average was 5.56 in Germany. On the other hand, there is a significant difference in musical interpretation score between the countries $(p<0.01)$. Mean musical interpretation score was 7.75 in Turkey, while it was 28.33 in Germany. 


\section{Conclusion, Discussion and Recomendations}

\section{Comparison Conclusions on the Inclusion of Flute Instruction Topics Based on School Years in Turkey and Germany}

Based on the comparison findings on the inclusion of flute instruction topics based on school years in Turkey and Germany, the following topics are instructed on the same years:

- Breathing practices are mostly conducted on the freshmen year in both Turkey and Germany.

- Vibrato technique is mostly instructed in the junior or senior year in both countries.

According to Toff (1996), diaphragm, throat and jaw are the mechanisms that enable the vibrato. The diaphragm provides both breath control and vibrato control with the same exercise method. According to this idea, the use of diaphragm and the breath should be achieved to create vibrato. Thus, the abovementioned case supports the findings of the present study in Turkey and Germany.

Fluttering technique is instructed intensively on the senior year in both countries. The smallest intervals, whistling sounds and glissando techniques are mostly instructed on the senior year. Multiphonics techniques concentrated on the junior and senior years in Turkey and on the senior year in Germany. Harmonics are mainly instructed on the senior year in Turkey and on the junior and senior years in Germany. Thus, it can be stated that the modern techniques are regarded as technically superior in both countries. It can be stated that in gammes with six flats and in gammes with seven sharps and seven flats and in chromatic gammes, the instruction is concentrated on the senior year in both countries. In general, this demonstrates that the methodology and systematics of the flute instructors in both countries are the same in the instruction of the abovementioned topics.

The topics that are instructed on the sophomore year in Turkey and on the junior year in Germany are as follows:

- Sonority is instructed intensively on the sophomore year in Turkey. In Germany, sonority is instructed mostly on the junior and senior years. The interval work is instructed on the sophomore year in Turkey, while it is instructed on the junior year in Germany. Arpeggios are instructed on the sophomore year in Turkey, while they are concentrated 
on the junior year in Germany. Gammes with three sharps are mostly instructed on the sophomore year in Turkey, while they are mostly instructed on the junior year in Germany. Gammes with three flats are mostly instructed on the freshmen and sophomore years in Turkey, while they are mostly instructed on the junior year in Germany.

The topics that are mostly instructed on the junior year in Turkey and on the senior year in Germany are as follows:

- Double tonguing technique is predominantly instructed on the junior year in Turkey, while it is instructed on the senior year in Germany. A similar situation is valid for the triple tonguing technique. Gammes with five flats, five sharps and six sharps are mostly instructed on the sophomore year in Turkey, while they are mostly instructed on the junior year in Germany. The instruction of the techniques that would enable color of sound and expression terms is predominantly instructed on the senior year in Turkey, while it is instructed on the junior year in Germany.

The topics that are mostly instructed on the freshman year in Turkey and on the junior and senior years in Germany are as follows:

- Gammes with one sharp, one flat, two sharps and twoflats.

The topics that are mostly instructed on the sophomore year in Turkey and on the senior year in Germany are as follows:

- Gammes with four flats and four sharps.

The topics that are mostly instructed on the freshman year in Turkey and on the junior and senior years in Germany are as follows:

- Gammes with no alteration.

\section{Conclusions on the Comparison of the Instruction Method Utili- zed in Turkey and Germany Based on the Flute Instruction To- pics}

Analysis of the findings on the comparison of the instruction method utilized in Turkey and Germany based on the flute instruction topics demonstrated that there was a significant difference between the two countries. In general, the most used methods in Turkey are the demonstration method, the method of music instruction through study/practice and the instruction method, respectively. It was observed that the most commonly used methods in Germany are the demonstration, instruction and question and answer 
methods.

In theoretical topics, it was determined that the most predominant method is the instruction method, on the other hand, in Germany, the most common methods are question and answer method and instruction method, respectively. On applied topics, the demonstration method and the method of music instruction through study/practice are the most common methods in Turkey, while the demonstration method is the most common method in Germany.

As a result of the analysis of the study findings, it is considered that the instruction method, which is the most adopted method in theoretical topics, is preferred due to its suitability for theoretical topics. But on the contrary, in Germany, it is observed that the preferred method is the question and answer method. In a study by Kürklü (2010), where the study group included flute instructors employed in Turkish secondary and higher education institutions, it was determined that the most common method was the instruction method in theoretical topics. The findings reported by Kürklü (2010) are consistent with the results of the present study.

\section{Conclusions on the Recommended Resources in Tone Develop- ment and Sonority, Gammes, Arpeggios, Intervals and Etude Exercises in Flute Instruction in Turkey and Germany}

The three most prominent resources recommended in tone development and sonority exercises in Turkey were Marcel Moyse; De La Sonorite, Marcel Moyse; Tone Development Through Interpretation and Trevor Wye; Practice book for the flute Vol. 1-Tone, while in Germany Marcel Moyse; De La Sonorite, Marcel Moyse; Tone Development Through Interpretation and Robert Dick; Tone Development Through Extended Techniques were recommended in Germany. It was observed that the most recommended two resources intone development and sonority exercises in Turkey and Germany were the same and the third resource was different. According to a study by Kara (2010) that compared the undergraduate flute instruction in Turkey and the US, \%79.41 of faculty members in Turkey $(\mathrm{N}=27)$ proposed the Marcel Moyse: De La Sonorite method, followed by Taffanel and Gaubert: 17 Grandes Exercises Journalieres de Mechanisme (N=23), Marcel Moyse: Tone Development Through Interpretation $(\mathrm{N}=18)$, Mathieu Reicheart: Exercises Journaliers $(\mathrm{N}=16)$ and Trevor Wye: Practise Book For The Flute Vol. 
1: Tone $(\mathrm{N}=12)$. Kara's findings were consistent with the present study results.

The three most prominent resources recommended in gammes, arpeggios and intervals exercises in Turkey were G. Gariboldi; Etude Complete des Gammes, op. 127, Marcel Moyse; Gammes et Arpeges and Th. W. Stepanow; Scales, Chords and Arpeggios, while Marcel Moyse; Gammes et Arpeges, Marcel Moyse; Mecanisme-Chromatisme (26.1\%) and Joachim Andersen; Schule der Virtuositat were the three most prominent resources recommended in scale, arpeggio and pitch exercises in Germany. It was determined that the recommended resources in scale, arpeggio and pitch exercises in Turkey and Germany were different. In a study by Uyan (2005), it was determined that W. Stepanow's "Scales, Chords and Arpeggios" was used in the freshman year in Turkish music teacher training departments. The study findings were consistent with the present study results in this respect. Kara (2010) determined that $44.11 \%(\mathrm{~N}=15)$ of the faculty members in Turkey used Stepanow's "The Scales, Chords and Arpeggios" method. These findings were consistent with the present study results.

The three most prominent resources recommended in etudes in Turkey were Ernesto Kohler; Op33/1 Fifteen Etudes, Ernesto Kohler; Op33/2 Twelve Etudes and Ernesto Kohler; Op33/3 Eight Etudes and Ernesto Kohler; Op66 Romantic Etudes, while Sigfrid Karg-Elert; Op107 Thirty Caprice, Andersen; 24 Etudes for Flute Op15 and Teobald Böhm; 24 Caprices- op.26 were the three most prominent resources recommended in etudes in Germany. It was determined that the recommended resources in etudes in Turkey and Germany were different.

\section{Conclusions on Flute Instruction Measurement and Evaluation in Turkey and Germany}

The findings on flute instruction measurement and evaluation in Turkey and Germany can be summarized as follows:

- It was concluded that there was no statistically significant difference between the countries in based on correct grip, playing with correct posture, playing with correct blowing technique, playing with correct tuning, playing with tone quality, playing with the right rhythm, playing with the style of tradition features, and playing with nuance. 
- On the other hand, scores for playing the correct note and correct articulation differed significantly among the countries. Thus, it was deduced that playing the correct note and correct articulation were prioritized in flute instruction in Turkey. There was a significant difference between the countries based on musical interpretation scores as well. Thus, it can be concluded that flute instruction in Germany emphasized musical interpretation better when compared to Turkey. This finding was parallel to the finding obtained in daily exercises sub-dimension that Germany devoted "more time to piece exercises," supporting the abovementioned finding.

In conclusion, there were similarities and differences between the flute instruction in music teacher training institutions in Turkey and Germany based on "inclusion of flute instruction topics in different school years", "instruction methods utilized based on the flute instruction topics", "recommended resources in tone development and sonority, gammes, arpeggios, intervals and etude exercises" and "measurement and evaluation in flute instruction" sub-dimensions.

Further studies could be conducted to contribute to flute instruction through detailed investigations on generally determined topics using observation or interview methods. In other studies, further data could be obtained on flute instruction by studying with flute instructors in various countries and different institutions using larger samples.

Studies can be conducted to investigate the causes of the differences between certain topics instructed in different years based on the findings related to the $1^{\text {st }}$ sub-problem in the present study. The results concerning the musical dimension of flute education, which were observed to be different in the German sample in the measurement and evaluation dimension in the $4^{\text {th }}$ study sub-problem, should be taken into consideration and the significance of this dimension should be assessed by flute educators. The effectiveness of the findings obtained in the German dimension of the study on Turkey could be determined with detailed empirical studies.

Previous studies revealed the significance of flute instruction, however although the significance of flute instruction in music teacher training in Turkey was mentioned, it is possible to claim that its emphasis was not sufficient. It would be beneficial to assign unique significance to flute education in curriculum development studies. From this perspective, it is important to 
work with flute instructors and curriculum developers.

Few scales are available in the literature to investigate flute education. Thus, it is important to establish standards and norms in order to assess flute education more comprehensively and to develop measurement instruments accordingly.

\section{References}

Ataman, G, Ö. (2010). Müzik öğretmeni yetiştiren kurumlardaki bireysel çalgı (flüt) ve ögretimi dersine yönelik flüt ögretim program tasarısı. Unpublished $\mathrm{PhD}$ thesis, Marmara Üniversitesi Eğitim Bilimleri Enstitüsü, İstanbul.

Cüceoğlu, G. (2002). Eğitim fakültelerinin güzel sanatlar eğitimi bölümü müzik ögretmenliği anabilim/anasanat dalı bireysel çalgı eğitimi i-ii (flüt) dersi için 'yerelden evrensele', 'bir öğretim programı model önerisi. Unpublished master thesis, Gazi Üniversitesi Eğitim Bilimleri Enstitüsü.

Cüceoğlu, G. (2006). 2001 yılından günümüze müzik öğretmenliği anabilim dallarında uygulanan bireysel çalgı ĕgitimi (flüt) öğretim programlarının değerlendirilmesi. Presented file by National Music Education Symposium, Pamukkale Üniversitesi Eğitim Fakültesi, Denizli.

Ekebalkan, S. (2007). Flüt eğitiminde çalışma yöntemlerinin teknik ve pedagojik açıdan incelenmesi. Unpublished master thesis, Dokuz Eylül Üniversitesi Güzel Sanatlar Enstitüsü.

Erginer, A. (2012). Avrupa Birliği ĕgitim sistemleri-Türkiye ĕgitim sistemiyle karşılaştırmalar.Ankara: Pegem Akademi.

EURYDİCE. (2013a). Das bildungswesen in der bundesrepublik Deutschland 2011/2012. Bonn: Sekretariat der Ständigen Konferenz der Kultusminister der Länder in der Bundesrepublik Deutschland, Graurheindorfer. http://www.istp2016.org/fileadmin/Redaktion/Dokumente/documentation/dos sier_de_ebook.pdf

Gedik, S. (1999). Gazi Üniversitesi Gazi Eğitim Fakültesi Müzik Ĕ̈itimi Bölümü 1995-1996 ögretim yılında hazırlanan tanım programının birinci yılına dayalı yeni bir flüt eğitimi taslak ögretim programı. Unpublished master thesis, Gazi Üniversitesi Fen Bilimleri Enstitüsü.

Hainmüller, B. (2003). Teachers training college in Offenburg, Germany. Offenburg. https://www.ltu.se/cms_fs/1.4767!/7c7da33e.pdf

İğdeli, R. (1994). Eğitim fakülteleri müzìk eğitimi bölümlerinde anadal flüt eğitimi nasıl olmalıdır. Unpublished master thesis, İnönü Üniversitesi Fen Bilimleri Enstitüsü.

Kara, E. Z. (2010). Türkiye ve Amerika Birleşik Devletlerinde lisans düzeyinde verilen flüt eğitiminin karşılaştırılması. Unpublished master thesis, Uludağ Üniversitesi Sosyal Bilimler Enstitüsü.

Keuchel, S. and Larue, D. (2014). Arts education in Germany - Fact Finding Mission Nr.1: German Resources and Structures of out-of-School Arts Education Provision.

http://www.educult.at/wp-content/uploads/2011/09/4_Annex_Mapping_Ger many.pdf 
Kürklü, E. (2010). Flüt ögrretiminde kullanılan öğretim yöntemlerinin konulara göre etkililiğinin değerlendirilmesi. Unpublished PhD thesis, Gazi Üniversitesi Eğitim Bilimleri Enstitüsü.

Meylan, R. (1988). The flute. Portland: Amadeus Press.

MiZ. (2011). Daten and Fakten zum Musikleben in Deutschland http://www.miz.org/musical-life-in-germany/download/press/Pressemitteilun g_Anhang_Daten_und_Fakten.pdf

Nimczik, O., Bassler, $\bar{H}$. and Altenburg, D. (2011). DeutschezMusikinformation szentrum in der Kulturstadt Bonn.

https://www.miz.org/musical-life-in-germany/download/Musical_Life_in_Ge rmany.pdf

Solum, J. (1992). The early flute. New York: Oxford University Press.

Tatu, A. G. (2008). Flüt metodu. İstanbul: Pan Yayıncilık.

Toff, N. (1996). The flute book (2. bask1). New York: Oxford University Press.

Uyan, T. Z. D. (2005) Üniversitelerin müzik öğretmenliği anabilim dalları birinci sınıf flüt eğitiminin ve bu eğitimde en yaygın kullanılan etüt ve eserlerin hedef ve davranışlar açısından incelenmesi. Unpublished master thesis, Gazi Üniversitesi Eğitim Bilimleri Enstitüsü.

Yayla, A, A. (2000) Güzel sanatlar eğitimi bölümü müzik ĕgitimi anabilim dalı flüt ögretiminde öğrencilerin psikomotor alan hedef ve davranıslara ulaşma düzeyleri. Unpublished master thesis, Pamukkale Üniversitesi Sosyal Bilimler Enstitüsü. 